\title{
Rising China and the Evolution of China-North Korea Relations
}

\author{
Hochul Lee
}

\begin{abstract}
China's foreign policies and behaviors with respect to the North Korean nuclear crises are conflicting or inconsistent, and therefore warrant scholarly explanation. China's policies and behaviors toward North Korea tend to fluctuate within a duplexity composed of the traditional alliance relationship and a newly evolved strategic cooperative relationship. Through analysis of China's policies and behaviors in dealing with the North Korean nuclear crises, this study confirms this duplexity and finds that its primary cause is the fact that China is rising, and is consequential in the process of the 'rising' and 'changing' of China's material capabilities and the ideational dimension of Chinese leaders. All told, the future of China -North Korea relations is more likely to be determined by a strategic cooperative relationship.
\end{abstract}

Key Words: rising China, China-North Korea relations, duplex relationship, traditional alliance relationship, strategic cooperative relationship, North Korean nuclear crises

$\mathrm{E}$ ven though China approved of the United Nations Security Council (UNSC) resolution 1718 in response to North Korea's first nuclear test on October 9, 2006, Beijing tried to abate the sanctions of the resolution by attaching reservations on its implementation. ${ }^{1}$ In addition, China did not approve of the practice of inspecting cargo to and from North Korea (United Nations Security Council 2006). China stressed a peaceful resolution to the nuclear crisis through 'dialogue and negotiations', while approving UNSC resolution 1874 against North Korea's second nuclear test on May 25, 2009 (United Nations Security Council 2009). China did not blame North Korea publicly for sinking of a South Korean patrol ship, ROKS Cheonan, on March 25, 2010, despite the fact that a multinational investigation concluded that the naval vessel was torpedoed by a North Korean submarine. Even when North Korea bombarded the South

*Hochul Lee (hochul82@gmail.com) is Professor of International Relations and China Studies at Incheon National University and Visiting Scholar at Weatherhead East Asian Institute, Columbia University. His recent publications include "China in North Korean Nuclear Crises: 'Interest' and 'Identity' in Foreign Behavior" (Journal of Contemporary China, March 2013) and "China's Rise and East Asian Security" in New Dynamics in East Asian Politics (Continuum International, 2012).

The research has been supported by Incheon National University 2012 Research Grant.

The Korean Journal of International Studies Vol.12 Special Issue (May 2014), 99-111. 
Korean-inhabited Yeonpyong Island on November 23, 2010, China remained silent. However, when North Korea conducted its third nuclear test on February 12, 2013, China explicitly cooperated with the United States in drafting and adopting the UNSC resolution 2094.

China's foreign policies and behaviors in relation to the North Korean nuclear crises and North Korea's provocations on the Korean peninsula have been seen as both conflicting and inconsistent. China's responses have been either reactive, as in the aftermath of the Cheonan incident, or proactive, as in the launching of the Six-Party Talks. This inconsistency and ambiguity demands explanation. Hence this study examines the nature and changes of China-North Korea relations.

This study finds that China's policies and behaviors toward North Korea tend to fluctuate within a duplex relationship composed of the traditional alliance relationship and a newly evolved strategic cooperative relationship. This duplexity is confirmed upon analysis of China's policies and behaviors in relation to the North Korean nuclear crises.The study also finds that the primary cause of the duplex relationship is the very fact that China is rising and concludes that the future of China-North Korea relations is more likely to be determined by a strategic cooperative relationship.

\section{THE DUPLEXITY OF CHINA-NORTH KOREA RELATIONS}

China-North Korea relations tend to revolve in a duplex relationship that is composed of the traditional alliance relationship and the newly evolved strategic cooperative relationship. While the traditional alliance relationship is still valid, a strategic cooperative relationship has also evolved as China has emerged as a great power since the mid-1990s. ${ }^{1}$

\section{TRADITIONAL ALLIANCE RELATIONSHIP}

China and North Korea concluded the Treaty of Friendship, Cooperation and Mutual Assistance in July 1961. The treaty comprehends a typical alliance relationship, whereby one party is committed to render military and other assistance by all means to the other against any outside attack.The alliance reflects Chinese leaders' 'buffer zone mentality'. Chinese leaders traditionally tend to perceive North Korea as a geopolitically important 'buffer zone' that blocks direct attacks on China possibly from the United States or Japan. Mao Zedong's

\footnotetext{
${ }^{1}$ In a similar context, International Crisis Group discerns two competing groups in China's North Korea policy debate, i.e., 'traditionalists' and 'strategists' (International Crisis Group 2009).
} 
remark on China-North Korea relations as close as 'lips and teeth' (脣亡齿寒), when stepping into the Korean War in 1950, typically reveals Chinese geopolitical perception of North Korea as a buffer zone (Lee 2013).

This buffer zone mentality is still alive and shared by many Chinese leaders and experts, especially within the party and the People's Liberation Army (PLA). For example, Liu Hongyang and Chen Dengyong (2010) and He Jingwen and Shen Yanjie (2010) consider preserving North Korea as a buffer zone as China's top strategic interest in dealing with the North Korean nuclear crisis. At the fiftieth anniversary of the treaty in 2011, Chinese president Hu Jintao and North Korean leader Kim Jong-il reportedly exchanged congratulatory telegrams. John Pomfret, an American journalist, argues that the buffer zone mentality is still valid in Chinese leaders' strategic thinking and will remain so even under the leadership of Xi Jinping (Pomfret 2013).

Within this traditional alliance relationship, China and North Korea share a special relationship built on the blood of hundreds of thousands of Chinese soldiers that was shed during the Korean War and North Korea, as a buffer zone between Chinese territory and American presence in South Korea, is not a strategic liability but a strategic asset (International Crisis Group 2009, 7). Therefore, China's top strategic priority is the survival of the North Korean regime and stability and status quo of the Korean peninsula rather than denuclearization of North Korea.

\section{STRATEGIC COOPERATIVE RELATIONSHIP}

However, as China's own reform and opening has deepened since the 1990s, China-North Korea relations have evolved into another phase, i.e., a normal relationship of strategic cooperation. As an emerging great power, China's foreign policies have also extended globally and revealed that China is tending to pursue more global strategic goals and interests. This global orientation reflects a newly evolved perception among Chinese leaders on the status and role of China as a 'responsible great power' (责任大国). Chinese leaders began to perceive China not as a great developing country but as a developing great country.

The diplomatic normalization with South Korea in 1992 in spite of North Korea's strong opposition marks the emergence of a new phase of China-North Korea relations. Chinese leaders and experts began to consider China's policies toward North Korea within a broad global strategic perspective, where strategic value of North Korea is not unconditionally given. Within this globally oriented strategic cooperative relationship, China tends to support North Korea selectively in tandem with its global strategic goals and interests. The Ministry of Foreign Affairs rather than the party or the PLA tends to be more sympathetic to this 
newly evolved relationship, with a heightened concern for global responsibility. Under this relationship, Chinese leaders might put higher priority on denuclearization of North Korea and preventing a nuclear domino in the region (i.e., Japan and/or South Korea going nuclear) than on protecting the North Korean regime unconditionally.

This newly evolved strategic cooperative relationship, however, has not replaced the traditional alliance relationship in China-North Korea relations. Rather, they coexist in an ambivalent or conflicting way. Sometimes China's North Korea policies are motivated by the traditional alliance relationship and at other times by the strategic cooperative relationship, with inevitable inconsistency and ambiguity. China's behaviors with respect to the North Korean nuclear crises typically reveal this duplexity.

\section{CHINA IN THE NORTH KOREAN NUCLEAR CRISES}

Table 1 below clearly shows that China's behaviors throughout the first and the second North Korean nuclear crises tend to traverse between those motivated by the traditional alliance relationship and those motivated by strategic cooperative relationship. The diplomatic normalization between China and South Korea in August 1992 marked the emergence of a new strategic thinking toward North Korea among Chinese leaders, by which China would not be strictly tied to the traditional alliance relationship but would rather pursue its global strategic goals and interests more flexibly. This might have provided background for North Korea's decision to develop a nuclear deterrent.

However, as the first nuclear crisis crept toward a potential military conflict between the United States and North Korea in spring 1994, China began to actively intervene to prevent a military clash and to restore stability in the Korean peninsula. Here, China's goal was to secure the survival of the North Korean regime and stability and status quo on the peninsula, not denuclearization per se of North Korea. Such was motivated more by its traditional alliance relationship with North Korea. The traditional alliance relationship was further confirmed by China's large-scale military exercise in the Liaodong peninsula in August 1994 to demonstrate its commitment to North Korea after the sudden death of North Korea's leader Kim Il-sung (see Table 1 below).

A similar pattern of the escalation of crisis is visible in March 2003. However, this time China's response to the crisis reflected more its global strategic goals and interests. Early in March 2003, China cut off oil pipeline to North Korea for three days to press the DPRK into talks with the United States. Then from July 2003 
onward, China invested a great deal of effort to set up a six-party talks to discuss the nuclear issue. Vice Foreign Minister Dai Bingguo shuttled to and from Pyongyang, Moscow and Washington to prepare the launch of the Six-Party Talks. Further, China played a key role in adopting the Joint Statement on September 19, 2005, at the Fourth Round of the Six-Party Talks, where the parties agreed to "verifiable denuclearization of the Korean Peninsula in a peaceful manner" in return for economic and energy aid along with security assurances to North Korea. All of these Chinese efforts were to exemplify a newly evolved strategic thinking toward North Korea, i.e., a strategic cooperative relationship in tandem with China's global strategic goals and interests as a responsible great power.

Nevertheless, when the UNSC was deliberating resolution 1718 to impose sanctions against North Korea for its first nuclear test in October 2006, China, even though it agreed on the sanctions, did not approve of inspecting cargo going to and coming from North Korea and attached reservations on the implementation of the sanctions so as not to endanger the North Korean regime (United Nations Security Council 2006). Similarly, when North Korea launched a long-range rocket, Kwangmyongsong 2, in violation of UNSC resolution 1718, in April 2009, China with Russia expressed sympathy with North Korea's claim to the sovereign right to peaceful space development.

After North Korea conducted its second nuclear test in May 2009, many Chinese experts argued for strong sanctions against North Korea and for a shift away from the traditional alliance relationship to a normal strategic relationship with North Korea. They pointed out that the North Korean nuclear tests could pose a security threat even to China and that China should do something in cooperation with the United States to press Pyongyang not to develop nuclear weapons. ${ }^{2}$ They consider China's global strategic goals and interests as more important than the 'buffer zone' provided by North Korea.

China, however, remained inclined toward the traditional alliance relationship. After North Korea's second nuclear test,in August 2009, within the Leading Small Group on Foreign Affairs, Chinese leaders and experts conducted an intense debate on whether North Korea is a strategic 'asset' (zichan) or a strategic 'liability' (fuzhai) for China, with two competing positions emerging: that China should try to stop North Korean nuclear development by all means including suspending oil and food aid and discard the buffer zone strategy because North Korean nuclear development could now be a security threat even to China; that China

2 "Duoming Zhongguo zhiming xuezhe zhichi gengjia yanlide zhicai chaoxian" (Several prominent Chinese Scholars support strengthening sanctions on North Korea), Huangiu Shibao (26 May 2009). 
should try to stabilize the North Korean regime first and that the nuclear issue should be resolved through the framework of the Six-Party Talks because North Korea is still a significant strategic asset to China as a buffer zone and the chaos that would result from a massive inflow of North Korean refugees in the event of a North Korean regime collapse should be prevented. Reportedly, the debate concluded with the line of "no war, no chaos, and no nukes" (无战, 无乱, 无核), revealing the order of priority of China's policies toward North Korea (ChosunIlbo 2013a; 2013b; International Crisis Group 2009, 6; Yoo 2013).

The conclusion implies that China-North Korea relations and the North Korean nuclear issue are to be separated and the bilateral relations are to be strengthened. The position reflecting the traditional alliance relationship (and buffer zone strategy) seems to have prevailed over the position reflecting a strategic cooperative relationship (and global concerns). In tandem with the decision of the Leading Small Group on Foreign Affairs, Chinese Premier Wen Jiabao visited Pyongyang in October 2009 and promised a massive economic aid package to North Korea.

North Korea's third nuclear test in February 2013, however, caused a reversal of China's North Korean policies more firmly toward the strategic cooperative relationship. North Korea conducted its third nuclear test in spite of the new Chinese leader Xi Jinping's clear message to Pyongyang not to do so, ${ }^{3}$ which in turn triggered a reexamination of China's North Korea policies within the policymaking circles, probably with Xi Jinping's firm instruction. In the perception of more and more Chinese leaders and experts,North Korea is being viewed as a 'strategic liability' rather than a 'strategic asset'. ${ }^{4}$ As a consequence, they argue for a policy shift away from ensuring the survival and stability of the North Korean regime toward denuclearization of North Korea and from a special relationship to a normal relationship. 5

A series of China's policy measures to implement the UNSC resolution 2094, in response to North Korea's third nuclear test, confirms the policy shift toward a strategic cooperative relationship while assuming more explicitly the responsibilities required by the resolution. In April 2013, China's Ministry of Transport sent an official document to its subordinate organizations that instruct them to

\footnotetext{
${ }^{3} \mathrm{Xi}$ Jinping sent Li Jianguo, a member of the Politburo, to Pyongyang with his letter urging the North Korean leadership not to launch ballistic missiles in November 2012 (New York Times 2013a).

${ }^{4}$ Deng Yuwen (2013), an analyst at the Central Party School, has raised probably the most radical argument that Beijing should now give up on Pyongyang and press for the reunification of the Korean peninsula.

${ }^{5}$ See the answer by Minister of Foreign Affairs of South Korea, Yun Byung-se, at a hearing in the National Assembly of South Korea (ChosunIlbo 2013c).
} 
implement strictly the UNSC resolution 2094. The same document was also sent to the offices of the People's Bank of China, Public Security, Customs Administration, and Border Guards (Jingjiribao, April 29, 2013). In May 2013, at the request of the US Treasury Department, the Bank of China, China Construction Bank, and other state-owned banks reportedly closed the accounts of the Foreign Trade Bank of North Korea and suspended its financial transactions related with nuclear and missile development. In September 2013, China's Ministry of Commerce, Ministry of Industry and Information Technology, General Administration of Customs, and Atomic Energy Authority jointly published a 236-page document that lists the items of dual-use products and technologies to be prohibited from export to North Korea. If put into place, this export control would be one of the strongest steps taken by China to try to limit North Korea's nuclear programs (NewYork Times 2013b). All of these measures taken under the Xi Jinping leadership indicate that China is now strictly implementing the sanctions required by the UNSC resolution and that China's North Korea policies will be conditioned more by a strategic cooperative relationship rather than by the traditional alliance relationship.

Overall, China's foreign-policy behavior in response to North Korea's nuclear crises has tended to fluctuate between the traditional alliance relationship and the newly evolved strategic cooperative relationship. The duplexity has led China to pursue somewhat incompatible goals and interests between ensuring the stability of the North Korean regime and seeking the denuclearization of North Korea. The former would secure China a buffer zone but endanger its global standing and risk potential conflict with the United States and a nuclear domino effect in the region. The latter would satisfy China's global strategic goals and interests but disturb the stability of the North Korean regime.

Table 1. China's Foreign Behaviors in the North Korean Nuclear Crises Revolving around the Duplex Relationship

\begin{tabular}{l|c|c}
\hline \multicolumn{1}{c|}{ Traditional Alliance Relationship } & Date & Strategic Cooperative Relationship \\
\hline $\begin{array}{l}\text { The US Pentagon develops a contingency } \\
\text { plan to bomb the Yongbyon nuclear facili- } \\
\text { ties if DPRK begins reprocessing (Niksch }\end{array}$ & August 1992 & China-ROK Diplomatic Normalization \\
$\begin{array}{l}\text { 2006); China begins behind-the-scene } \\
\text { diplomacy to persuade DPRK to talk with } \\
\text { the US }\end{array}$ & & \\
$\begin{array}{l}\text { China's large-scale military exercise in the } \\
\text { Liaodong peninsula to demonstrate its } \\
\text { commitment to DPRK after death of Kim II- } \\
\text { sung }\end{array}$ & August 23,1994 & \\
\hline
\end{tabular}




\begin{tabular}{|c|c|c|}
\hline \multirow[t]{2}{*}{ Traditional Alliance Relationship } & Date & Strategic Cooperative Relationship \\
\hline & October 25, 2002 & $\begin{array}{l}\text { Jiang Zemin stresses the significance of } \\
\text { nuclear-free Korean peninsula at the } \\
\text { meeting with US president George Bush } \\
\text { at Bush's private ranch in Crawford, Texas }\end{array}$ \\
\hline & February 18, 2003 & $\begin{array}{l}\text { Vice Foreign Minister Wang Yi warns } \\
\text { DPRK Foreign Minister Paik Nam-sun that } \\
\text { DPRK should not cross the red line set by } \\
\text { the US on a moratorium on reprocessing } \\
\text { and that further provocations would } \\
\text { endanger China-DPRK relations (Ming Liu } \\
\text { 2003) }\end{array}$ \\
\hline & (1) & $\begin{array}{l}\text { China cuts off oil pipeline to DPRK for } 3 \\
\text { days in the middle of increasing military } \\
\text { tension between the US and DPRK, while } \\
\text { the US reviews military options including } \\
\text { surgical strike, bombing, and even using } \\
\text { tactical nuclear weapon (Kristof 2003; } \\
\text { Schifferes 2003) }\end{array}$ \\
\hline & July 2003 & $\begin{array}{l}\text { Vice Foreign Minister Dai Bingguo shuttles } \\
\text { to and from Pyongyang, Moscow and } \\
\text { Washington to launch SPT }\end{array}$ \\
\hline & September 2005 & $\begin{array}{l}\text { The } 4^{\text {th }} \text { round } 2^{\text {nd }} \text { phase of SPT adopts } \\
\text { Joint Statement where the parties agreed } \\
\text { to "verifiable denuclearization of the } \\
\text { Korean Peninsula in a peaceful manner" } \\
\text { in return for economic and energy aid } \\
\text { along with security assurances to DPRK, } \\
\text { where China plays a key role in resuming } \\
\text { the talks and drafting a joint statement }\end{array}$ \\
\hline $\begin{array}{l}\text { UNSC resolution } 1718 \text { to impose sanc- } \\
\text { tions on DPRK for the 1st nuclear test; } \\
\text { though China agrees to the sanctions, it } \\
\text { does not approve of inspecting cargo to } \\
\text { and from DPRK, adding reservations on } \\
\text { their implementation (United Nations } \\
\text { Security Council 2006) }\end{array}$ & October 2006 & \\
\hline $\begin{array}{l}\text { DPRK launches a long-range rocket, } \\
\text { Kwangmyongsong 2, in violation of UNSC } \\
\text { resolution 1718; in UNSC, China with } \\
\text { Russia express sympathy for DPRK's claim } \\
\text { to the right to peaceful space development }\end{array}$ & April 2009 & \\
\hline & May 2009 & $\begin{array}{l}\text { Xi Jinping, Vice President of China, } \\
\text { remarks that DPRK nuclear test goes } \\
\text { against China's principle and interest }\end{array}$ \\
\hline $\begin{array}{l}\text { After DPRK's } 2 \text { nd nuclear test in May } \\
2009 \text {, Chinese leaders conduct a debate } \\
\text { in the Leading Small Group on Foreign } \\
\text { Affairs and conclude that DPRK is more a } \\
\text { 'strategic asset' than a 'strategic liability' } \\
\text { ("no war, no chaos, no nuke") (Chosunllbo } \\
2013 \text { b) }\end{array}$ & August 2009 & \\
\hline
\end{tabular}




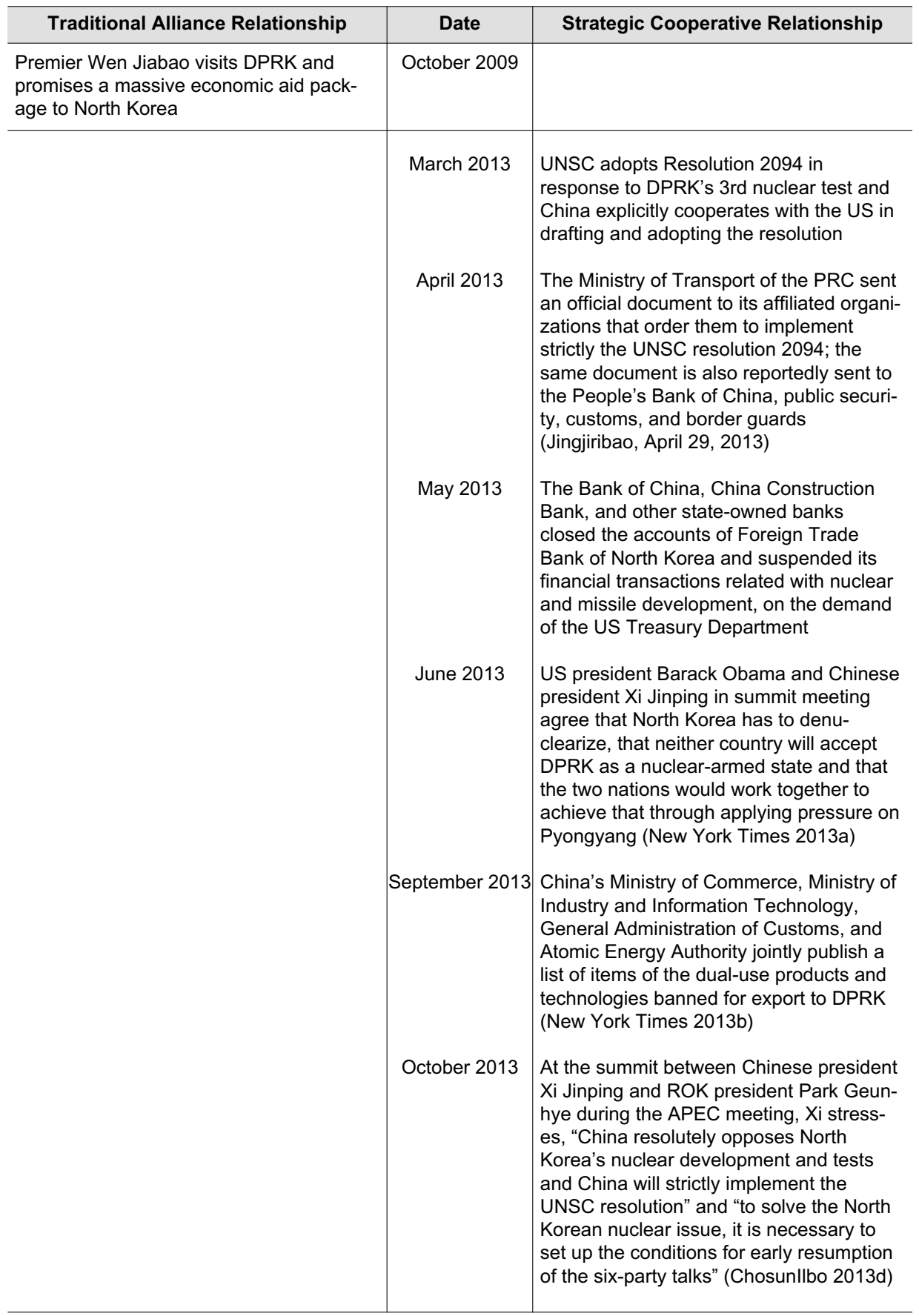




\section{RISING CHINA AS A CHANGING CHINA}

Why the duplexity in China's relationship with North Korea and what explains the consequent inconsistency and ambiguity in China's behavior related to the North Korean nuclear crises? First of all, we might consider the competing perceptions of China's interest in its relations with North Korea as the primary cause of the duplex relationship. The debate between Chinese 'traditionalists' and 'strategists' after North Korea conducted its second nuclear test in May 2009 highlight the difference in their perceptions on China's vital interest toward North Korea and consequently in their policy priorities. While the traditionalists still consider maintaining North Korea as a buffer zone as the most important geopolitical national interest in the power transition between the United States and China, the strategists argue that China now has to pursue more globally oriented goals and interests including nonproliferation and active peacebuilding in a new type of great power relations with the United States.

However, different perceptions on interest reflect more fundamental changes in ideational aspects within the Chinese policymaking circles. China's economic and military capabilities have been improving for last three decades. Physical changes are naturally accompanied by psychological changes. Accordingly ideational changes within the policymaking circles (i.e., the changes in their mentalities, perceptions, ideas, and identities) have followed the growing material capabilities. As material capabilities are growing, new identities are evolving simultaneously while old identities remain influential. Consequently, China's foreign policies and behaviors are characterized by uncertainty and inconsistency. In short, the rising China is a changing China.

As Jia Qingguo aptly points out, since China is in the process of rising, China shows conflicting identities and interests in its foreign policies (Jin Qingguo 2012). Thus, China's foreign policies and behaviors are sometimes reactive but at other times proactive, sometimes accommodating but at other times constructive. They are sometimes faithful to Deng Xiaoping's guideline of 'taoguangyanghui' (蹈光养晦) but at other times guided by a newly evolved identity of 'zerendaguo' (责任大国). Similarly China's policies and behaviors toward the North Korean nuclear crises have been driven by a traditional 'buffer zone mentality' sometimes but by a newly evolved 'zerendaguo mentality' at other times (Lee 2013).

In short, the rising China implies a changing China with multiple identities remaining influential but without a clear and agreed upon vision of the regional and global order. Hence the duplex relationship is not intended but consequential in the process of 'rising' and 'changing'. 


\section{CHINA-NORTH KOREA RELATIONS IN THE FUTURE}

Since the 1990s, China-North Korea relations have evolved toward a strategic cooperative relationship. However, the newly evolved relationship has not replaced the traditional alliance relationship. Rather, the two coexist in an ambivalent and conflicting way. This duplexity in China-North Korea relations explains China's inconsistent policies toward North Korea as shown through the evolution of the North Korean nuclear crises. The duplexity in the relationship in turn is reflective of transitional identities of the rising China.

However, as China expands its interests more globally, China-North Korea relations will shift more toward a strategic cooperative relationship from the traditional alliance relationship. This trend is likely to be reinforced under the Xi Jinping leadership, as Table 1 above shows. ${ }^{6}$ Furthermore, the 'new model for great power relations' which Xi Jinping suggested to US president Barack Obama as a new guideline in the future of US-China relations during their summit meeting in June 2013 would be another reinforcing factor. The new model represents three key points: no confrontation (不对抗), mutual respect (相互尊重), and winwin cooperation (合作共贏). If the Xi Jinping leadership is really willing to realize this new model in US-China relations, China should take into account more global concerns and assume more global responsibility while maintaining constructive cooperation with the United States. China's efforts to realize the new model in US-China relations then are likely to push China-North Korea relations more toward a strategic cooperative relationship (Kim 2013).

Figure 1. Evolution of China's North Korea Policies

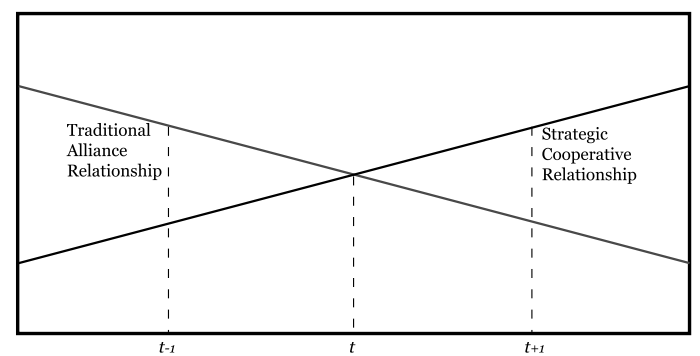

Figure 1 above summarizes and simplifies the evolution of China's North Korea policies. Based on China's foreign policies and behaviors with respect to the North

\footnotetext{
${ }^{6}$ Heungkyu Kim (2013) might agree on this point, whereas DongwonYoo (2013) might not.
} 
Korean nuclear crises over the last two decades (as summarized in Table 1), the scope of the traditional alliance relationship tends to decrease, while the scope of the strategic cooperative relationship tends to increase. Thus, at time t-1,the traditional alliance relationship more determines China's North Korea policies; at time, the traditional alliance and the strategic cooperation equally determine them; at time $t+1$, the strategic cooperation more determines them.

Considering China's North Korea policies under the Xi Jinping leadership since November 2012, so far as summarized in Table 1 above and the new model for great power relations that Xi Jinping suggested to Barack Obama at their summit meeting, China's North Korea policies seem to have passed the area of time and are moving toward the area of time $t+1$, where they are more likely to be determined by a strategic cooperative relationship. Figure 1 above also indicates that the traditional alliance relationship would not disappear completely even in the area of time $t+1$. Even though the scope of the traditional alliance relationship decreases below that of a strategic cooperative relationship, it will not completely disappear until a new framework like a peace regime replacing the armistice or a reunification of the Korean peninsulais agreed on among related countries.

\section{REFERENCES}

Chosun Ilbo. 2013a. Chosun Ilbo (January 26), A6.

Chosun Ilbo. 2013b. Chosun Ilbo (February 15), A3.

Chosun Ilbo. 2013c. Chosun Ilbo (June 12), A4.

Chosun Ilbo. 2013d. Chosun Ilbo (October 8), A1.

Deng Yuwen. 2013. "China Should Abandon North Korea." Financial Times (February 27). Accessed at www.ft.com/cms/s/o/9e2f68b2-7c5c-11e299fo-00144feabdco.html\#ixzz2MGAGQDnY.

He, Jingwen and Shen Yanjie. 2010. "Zhongguo zai Chaoxian hewenti zhong de lichang he zhengce xuanze" (China's position and policy choice on the North Korean nuclear issue). Xuebao (Study Journal) 5, 45-46.

Huanqiu Shibao. 2009. "Duoming Zhongguo zhiming xuezhe zhichi gengjia yanlide zhicai Chaoxian" (Several prominent Chinese scholars support strengthening sanctions on North Korea). Huanqiu Shibao (May 26).

International Crisis Group. 2009. "Shades of Red: China's Debate over North Korea." Asia Report 179 (November).

Jia, Qingguo. 2012. "China on the Rise and Changing East Asian Order." Paper presented at the International Conference on Peace in the Korean Peninsula and Cooperation in East Asia: Opportunities and Challenges. 
(August 20-21).

Jingjiribao (經濟日報). 2013. Jingjiribao (April 29).

Kim, Heungkyu. 2013. "Changes in China-North Korea Relations and Their Implication." Hanbando Focus 24, 13-15.

Kim, Heungkyu. 2013. "Prospects for a New Type of Sino-US Great Power Relations and Policies on the Korean Peninsula during the Xi Jinping Era." Gukbang Yeongu 56(3), 27-54.

Kristof, Nicholas D. 2003. "Secret, Scary Plans.” New York Times (February 28). Lee, Hochul. 2013. "China in the North Korean Nuclear Crises: 'Interest' and 'Identity' in Foreign Behavior." Journal of Contemporary China 22(80), 312-331.

Liu Hongyang and Chen Dengyong. 2010. "Jianxi Chao hewenti dui Zhongguo anquan de yingxiang ji duice" (An analysis of the impact of the North Korean nuclear issue on Chinese security and the measures needed). Fazhi yu Shehui (Legal System and Society), 208-209.

Liu, Ming. 2003. "China and the North Korean Crisis: Facing Test and Transition." Pacific Affairs 76(1), 347-373.

"North Korean Leader, Young and Defiant, Strains Ties With Chinese." 2013a. New York Times (April 13). Accessed at www.nytimes.com/2013/04/14/ world/asia/kim-jong-un-tests-relations-with-china.html?_r=o

"China Bans Items for Export to North Korea, Fearing Their Use in Weapons." 2013b. New York Times (September 24). Accessed at www.nytimes.com/ 2013/o9/25/world/asia/china-bans-certain-north-korean-exports-forfear-of-weapons-use.html?_r=o

Niksch, Larry A. 2006. "North Korea's Nuclear Weapons Program.” CRS Issue Brief for Congress.

Pomfret, John. 2013. "Why China Won't Act Against a Nuclear North Korea." Washington Post (March 23).

Schifferes, Steve. 2003. "US Splits Deepen over North Korea." BBC News (June 18). Accessed at http://news.bbc.co.uk/2/hi/americas/2999066.stm

United Nations Security Council. 2006. Press Release. Accessed at www.un.org/ News/Press/docs/2006/sc8853.doc.htm

United Nations Security Council. 2009. Press Release. Accessed at www.un.org/ News/Press/docs/2009/ sc9679.doc.htm

Yoo, Dongwon. 2013. "The Change of China's North Korea Policy: Possibility and Constraint." Gukbang Yeongu 56(3), 1-25. 